\title{
PARTIPASI MASYARAKAT DALAM KEBERLANJUTAN PROGRAM (PAMSIMAS) PENYEDIAAN AIR BERSIH DAN SANITASI BERBASIS MASYARAKAT DI DESA AENG DAKE KECAMATAN BLUTO TAHUN 2019
}

\author{
Laylatul Hasanah \\ Fakultas Ilmu Kesehatan, Universitas Wiraraja \\ Jl. Raya Sumenep-Pamekasan KM. 05 Patean, Panitian Utara, Patean, Batuan, Kabupaten \\ Sumenep, Jawa Timur 69451
}

\begin{abstract}
Abstrak
Penyediaan Air Minum dan Sanitasi Berbasis Masyarakat adalah salah satu program yang dilaksanakan oleh Pemerintah Indonesia dengan dukungan Bank Dunia, program ini dilaksanakan di wilayah perdesaan dan pinggiran kota. Program penyediaan air minum dan sanitasi berbasis masyarakat bertujuan untuk meningkatkan jumlah fasilitas pada warga masyarakat kurang terlayani termasuk masyarakat berpendapatan rendah di wilayah perdesaan dan peri-urban, dengan program penyediaan Air minum dan sanitasi berbasis masyarakat diharapkan mereka dapat mengakses pelayanan air minum dan sanitasi yang berkelanjutan serta meningkatkan penerapan perilaku hidup bersih dan sehat. Metode Penelitian ini menggunakan metode deskriptif. Obyek penelitian diantaranya 1 pelaksana Program penyediaan Air minum dan sanitasi berbasis masyarakat di Dusun Tambiyu Desa Aengdake Instrumen penelitian menggunakan lembar wawancara, dan lembar observasi yang menggambarkan program penyediaan Air minum dan sanitasi berbasis masyarakat di Dusun Tambiyu Desa Aengdake. Hasil penelitian didapatkan hasil 95\% dari 72 rumah masyarakat yang ikut berpartisipasi dalam perencanaan, pelaksanaan sampai dengan pemeliharaan program penyediaan Air minum dan sanitasi berbasis masyarakat memiliki pola hidup bersih dan sehat.
\end{abstract}

Kata Kunci : Partisipasi Masyarakat; Program penyediaan Air minum dan sanitasi berbasis masyarakat; Dusun Tambiyu Desa Aengdake

\begin{abstract}
Abtract
The Drinking water supplies and community based sanitationprogramimplemented by the indonesian government with support of the world bank, this program was conducted in rural areas and suburbs. The aims of drinking water supplies and community based sanitation programto increase the proportion of facilities in the society less served including the low income in rural areas and peri-urban, the drinking water supplies and community based sanitation program they are expected to access fresh water and sanitation services and improve the implementation of sustainable clean and healthy behaviors. The research was used descriptive. Objects of research program is 1 managers of drinking water supplies and community based sanitation program, this research instruments using interview sheet, and observation sheet. The research results obtained 95\% of 72 household participate in planning under the implementation of the the drinking water supplies and community based sanitationprogramhaving more clean and healthy lifestyle.
\end{abstract}

Keywords : Community participation; Drinking water supplies and community based sanitation program; hamlet village tambiyu aengdake 


\section{Latar Belakang}

Sarana dan Prasarana serta Infrastruktur merupakan salah satu aspek penting dalam perencanaan pembangunan suatu daerah atau kota. Fungsi keterkaitan antar ruang dan kegiatan, infrastruktur memiliki peran penting terhadap perubahan kesehatan, peningkatan ekonomi masyarakat dan kemakmuran wilayah yang memiliki kontribusi penting dalam aspek perekonomian, sosial kemasyarakatan, maupun kelestarian lingkungan.

Salah satunya adalah pemenuhan kebutuhan air minum dan sanitasi sebagai kebutuhan mutlak kehidupan. Keberadaannya berperan besar dalam mewujudkan kesehatan masyarakat masih terkendala pada keterbatasan pelayanan infrastruktur (ketersediaan sarana, jangkauan pelayanan, pengelolaan).

Sanitasi dan perilaku kebersihan yang kurang baik serta air minum yang tidak aman berkontribusi terhadap $88 \%$ kematian anak akibat diare di seluruh dunia. Bagi anak-anak yang bertahan hidup, seringnya menderita diare berkontribusi terhadap masalah gizi, sehingga menghalangi anak-anak untuk dapat mencapai potensi maksimal mereka. Kondisi ini selanjutnya menimbulkan implikasi serius terhadap kualitas sumber daya manusia dan kemampuan produktif suatu bangsa di masa yang akan datang.

Di Indonesia, diare masih merupakan penyebab utama kematian anak berusia di bawah lima tahun. Laporan Riskesdas 2007 menunjukkan diare sebagai penyebab 31 persen kematian anak usia antara 1 bulan hingga satu tahun, dan $25 \%$ kematian anak usia antara satu sampai empat tahun. Angka diare pada anakanak dari rumah tangga yang menggunakan sumur terbuka untuk air minum tercatat $34 \%$ lebih tinggi dibandingkan dengan anak-anak dari rumah tangga yang menggunakan air ledeng, Selain itu, angka diare lebih tinggi sebesar $66 \%$ pada anak-anak dari keluarga yang melakukan buang air besar di sungai atau selokan dibandingkan mereka pada rumah tangga dengan fasilitas toilet pribadi dan septik tank.
Pertumbuhan penduduk yang terus meningkat menyebabkan penggunaan air semakin tinggi. Kebutuhan terhadap kuantitas juga kualitas air pun turut meningkat. Air yang tercemar menimbulkan berbagai macam penyakit, tak menutup kemungkinan menjadi penyebab kematian. Tiap tahunnya sebanyak 1,7 juta anak tewas akibat diare yang disebabkan karena lingkungan yang tidak sehat, terutama karena air yang tercemar.

Survei Sosial Ekonomi Nasional (Susenas) oleh Badan Pusat Statistik (BPS) mencatat adanya peningkatan rumah tangga yang memiliki akses terhadap sumber air minum layak di Indonesia. Pada 2012 hanya 65,05\% rumah tangga memiliki akses terhadap sumber air minum layak. Pada 2014, sebanyak $68,11 \%$ rumah tangga punya akses tersebut. Angka ini naik lagi di 2017 menjadi 72,04\%.

Target 7C Millennium Development Goals (MDGs) adalah menurunkan hingga separuhnya proporsi penduduk tanpa akses terhadap sumber air minum yang aman dan berkelanjutan serta fasilitas dasar pada tahun 2015. Menurut target MDGs pelayanan air minum perpipaan nasional pada tahun 2015 adalah mencapai 57,4 \% (Bappenas, 2007). Berdasarkan laporan capaian tujuan pembangunan millennium di Indonesia tahun 2011 proporsi rumah tangga dengan akses berkelanjutan terhadap sumber air minum layak meningkat dari $37,73 \%$ (1993) menjadi 42,76 \% (2011),sedangkan untuk fasilitas sanitasi dasar layak dari $24,81 \%$ (1993) menjadi 55,60 \% (2011) (Bappenas, 2011).

Bentuk upaya untuk menanggulagi masalah ketersediaan air bersih dan derajat kesehatan lingkungan masyarakat yang menurun akibat kondisi sarana dan prasarana sanitasi yang buruk di pedesaan yaitu dengan Program Penyediaan Sarana Air Minum dan Sanitasi Berbasis Masyarakat (pamsimas) yang mendapat dukungan penuh oleh Kementerian Pekerjaan Umum dan Kementerian Kesehatan. Pembangunan yang titik bertanya berada pada strategi pembangunan dari bawah ke atas yang didasari oleh mobilitas sumberdaya manusia, alam, dan kelembagaan dengan tujuan memenuhi 
kebutuhan dasar masyarakat. Penyediaan Air Minum dan Sanitasi Berbasis Masyarakat (pamsimas) adalah salah satu program yang dilaksanakan oleh Pemerintah Indonesia dengan dukungan Bank Dunia, program ini dilaksanakan di wilayah perdesaan dan pinggiran kota. Program Pamsimas bertujuan untuk meningkatkan jumlah fasilitas pada warga masyarakat kurang terlayani termasuk masyarakat berpendapatan rendah di wilayah perdesaan dan peri-urban, dengan Pamsimas, diharapkan mereka dapat mengakses pelayanan air minum dan sanitasi yang berkelanjutan serta meningkatkan penerapan perilaku hidup bersih dan sehat. Penerapan program ini dalam rangka mendukung pencapaian target MDGs (sektor air minum dan sanitasi) melalui pengarusutamaan dan perluasan pendekatan pembangunan berbasis masyarakat.

Program Pamsimas I dilaksanakan pada tahun 2008 sampai tahun 2012 di 110 Kabupaten/Kota dari 15 Provinsi. Pamsimas I berhasil diterapkan pada 6.845 (enam ribu delapan ratus empat puluh lima) desa, terdiri dari 6.262 (enam ribu dua ratus enam puluh dua) desa reguler dan sekitar 593 (lima ratus sembilan puluh tiga) desa replikasi.

Program Pamsimas II dilaksanakan pada tahun 2013 sampai dengan 2016. Program Pamsimas II ditargetkan akan dilaksanakan di sekitar 5000 desa di 32 provinsi di $220 \mathrm{Kab} /$ Kota. Proses pemilihan desa untuk program Pamsimas dilakukan dengan cara sosialisasi tingkat kabupaten. Proses ini bertujuan untuk menginformasikan pelaksanaan program air minum yang akan dilaksanakan dan dikelola di wilayah kabupaten. Selanjutnya adalah sosialisasi program tingkat desa yang bertujuan untuk menjaring peminatan warga masyarakat desa mengenai partisipasi dalam program bantuan air minum dan sanitasi.

Kabupaten Sumenep merupakan salah satu Kabupaten sebagai lokasi program Pamsimas, total kegiatan program Pamsimas ada 8 lokasi sasaran program Pamsimas tersebut yakni daerah Batang-batang, Desa Batang-batang Daya, Kecamatan Lenteng Desa Tarogan, Kecamatan Ganding Desa Bataal Barat, Kecamatan Pragaan Desa Rombasan,
Kecamatan Ambunten Desa Keles dan Kecamatan Bluto Desa Aeng Dake.

Dusun Tambiyu Barat desa Aeng Dake merupakan salah satu sasaran desa yang menjadi lokasi Pamsimas hal tersebut berkaitan dengan jumlah masyarakat yang tidak memiliki MCK dan Akses air bersih cukup, jumlah sasaran 72 rumah, yang awalnya masyarakat mengakses air bersih yang langsung bersumber dari alam dan dengan akses sanitas yang minim, hal tersebut mengakibatkan terjadinya perilaku hidup bersih dan sehat yang buruk pada masyarakat, yakni masyarakat menggunakan sumur terbuka dan sumber alam terbuka sebagai salah satu sarana untuk mengakses air bersih dan sebagai sarana kegiatan MCK. adanya program tersebut diharapkan masyarakat dapat dengan mudah mengakses air bersih dan merubah perilaku hidup bersih dan sehat menjadi lebih baik.

\section{METODE}

Penelitan ini menggunakan metode deskriptif. Menurut Arikunto dinyatakan bahwa penelitian deskriptif adalah penelitian yang dimaksudkan untuk menyelidiki keadaan, kondisi atau hal lain-lain yang sudah disebutkan yang hasilnya dipaparkan dalam bentuk laporan penelitian. Obyek ini diantaranya petugas penyelenggara program Pamsimas di Dusun Tambiyu Desa Aeng Dake Kecamatan Bluto. Instrumen penelitian menggunakan lembar wawancara, dan lembar observasi menggambarkan partisipasi masyarakat dalam keberlanjutan program Pamsimas di Desa Aengdake.

\section{HASIL DAN PEMBAHASAN}

Berdasarkan hasil wawancara pada Informan Tahap perencanaan dalam program Pamsimas dibahas pada pertemuan yang diadakan oleh Kepala Desa dengan aparat desa, untuk membahas kebutuhan masyarakat akan program tersebut. Partisipasi dalam bentuk sumbangan pikiran, keaktifan dalam berdiskusi rencana kegiatan Program tersebut. Pada tahap perencanaan masyarakat diminta untuk memberikan bentuk partisipasi yang akan 
diberikan baik secara material, ide, kritik saran, tenaga dan bentuk sumbangan lainnya . Pada tahap ini masyarakat banyak yang memilih menjawab dengan memberikan sumbangan tenaga, hal ini berkaitan dengan tingkat ekonomi masyarakat di Dusun Tambiyu Desa Aeng dake yang memiliki pendapatan tidak tetap.

Masyarakat sebagai penerima bantuan program Pamsimas sebanyak 72 rumah dan 18 ladang mendapatkanhasil yang memuaskan, karena awalnya Masyarakat di Dusun Tambiyu Desa Aengdake 98\% menggunakan air dari sumber mata air langsung mengaku cukup kesulitan air bersih, apalagi pada saat musim kemarau. 95\% masyarakat yang mendapatkan program Pamsimas ikut berpatipasi dalam perencanaan sampai dengan tahap pemeliharaan, 5\% dari masyarakat di Dusun Tambiyu Desa Aeng Dake tidak ikut berpatisipasi hal tersebut berkaitan dengan kepemilikan sumur bor yang dimiliki secara mandiri. Fasilitas Pamsimas yang disediakan oleh pemerintah di Dusun Tambiyu Desa Aengdake terdiri dari 1 tandon, 1 sumur bor dan 1 bak pelepas tekan. Partisipasi yang diberikan oleh masyarakat berupas sumbangan rutin yaitu 3000 rupiah setiap rumah dengan ketentuan apabila dengan secara sengaja mencabut aliran air maka akan denda sebanyak 70 ribu rupiah.

Partisipasi masyarakat pada program Pamsimas ini berupa pemeliharaan untuk dapat dilanjutkan sebagai program berkelanjutan misalnya adanya sarana prasarana MCK dengan air bersih yang memadai sehingga dapat merubah pola hidup bersih sehat masyarakat agar menjadi lebih baik. Bentuk partisipasi pemeliharaan yang diberikan oleh masyarakat Dusun Tambiyu Desa Aengdake berupa biaya pemeliharaan pada sarana air bersih dan sarana sanitasi jika terjadi kerusakan.

\section{Kesimpulan}

Program Pamsimas di Dusun Tambiyu Desa Aeng Dake 98\% masyarakat sebanyak 72 rumah dan 18 ladang sudah mendapatkan penyediaan air bersih dan sanitasi berbasis masyarakat sehingga hal tersebut dapat merubah pola hidup bersih dan sehat. Dari 72 rumah yang mendapatkan program tersebut 95\% ikut berpartisipasi dalam perencanaan sampai dengan pemeliharaan 5\% tidak ikut berpartisipasi dikarenakan masyarakat memiliki sumur bor mandiri.

\section{Daftar Pustaka}

Anonim, POKJA AMPL Program Nasional Penyediaan Air Minum dan Sanitasi Berbasis Masyarakat (PAMSIMAS) 2017

Anonim,petunjuk Teknis penguatan keberlanjutan Program Sanimas, 2013

Anonim, Program Umum Penyediaan Air Minum dan Sanitasi BerbasisMasyarakat, 2016

Anonim, petunjuk Teknis Program Nasional Penyediaan Air minum dan Sanitasi Berbasis Masyarakat DesaAeng DakeKecamatan BlutoKabupaten Sumenep, 2013

Anonim, pedoman pelaksanaan pamsimas di tingkat masyarakat desember 2006

Afriandi, Wahyono 2012 partisipasi masyarakat dalam program penyediaan air minum dan Sanitasi Berbasis Masyarakat di Kecamatan Simpur Kabupaten Hulu Sungai Selatan Kecamatan Tilamuta Kabupaten Boalemo, Goronotalo.

Chaerunnissa, 2104 partisipasi masyarakat dalam program penyediaan air minum dan Sanitasi Berbasis Masyarakat di Kabupaten Brebes

Nofiandi, 2014 Peran masyarakat dalam melaksanakan program pamsimas di desa banjarsari kecamatan gajah kabupaten demak 
Maharani, 2015 Hubungan Pelaksanaan

Program PAMSIMAS dengan

Perilaku Hidup Bersih dan Sehat Masyarakat (Studi di Desa Merpang Kecamatan Runjung Agung Kabupaten OKU Selatan)

Ibrahim, Surotinojo (2009) partisipasi masyarakat dalam program Sanitasi Berbasis Masyarakat di Desa Bajo 